\title{
Inhibitory effects of urine on the polymerase chain reaction for cytomegalovirus DNA
}

\author{
G Khan, H O Kangro, P J Coates, R B Heath
}

\begin{abstract}
The inhibitory effects of urine samples taken from neonates and older children, some of which were known to be infected with cytomegalovirus, on the polymerase chain reaction (PCR) were investigated. Urea was the major inhibitory component of urine and inhibited the PCR at a concentration of more than $50 \mathrm{mM}$. Urine samples from older children were more inhibitory than those from neonates. This correlated with the higher concentration of urea generally found in urine samples from older children compared with neonatal urines. Two of 13 neonatal urine samples, however, were inhibitory despite low urea concentrations-presumably due to metabolites derived from parenteral nutrition. The inhibitory effects of urine were effectively removed by simple dialysis or ultrafiltration. The sensitivity and specificity of PCR for detecting cytomegalovirus DNA in urine were further improved by using "nested" primers and a modified PCR protocol entailing the use of reduced reactants in the first 20 cycles of a twostage 50 cycle PCR.
\end{abstract}

Human cytomegalovirus (CMV) is a common infectious agent which can cause severe morbidity and mortality in immunocompromised patients, such as allograft recipients and patients with AIDS. ${ }^{12}$ CMV infection during pregnancy is also recognised as a major viral cause of abnormalities in the newborn. ${ }^{3}$ Isolation of CMV from urine or throat swabs in human embryonic fibroblast cultures is the definitive method of diagnosing congenital CMV infection but can take up to three weeks to perform. Hence there is a need for a more rapid and convenient method. The DEAFF test $^{4}$ can reduce the time required to $24-48$ hours but still requires virus infectivity and appropriate monoclonal antibodies.

Alternative methods for detecting CMV in urine have been used including electron microscopy, antigen detection by enzyme linked immunosorbent assay (ELISA), and viral DNA detection by nucleic acid hybridisation. ${ }^{5}$ None of these, however, meets all the required criteria of being rapid, specific, and sensitive.

The development of the polymerase chain reaction (PCR) ${ }^{6}$ has had a great impact on many areas of molecular medicine. It has been used for the diagnosis of genetic disorders such as cystic fibrosis and sickle cell anaemia, ${ }^{7}$ as well as for the detection of latent or persistent viruses, including the herpes viruses and human immunodeficiency virus (HIV). ${ }^{8}$ PCR permits the in vitro amplification of specific DNA sequences by a factor of $10^{6}$ or more within a few hours and is, therefore, potentially very sensitive. It is based on an enzymatic reaction involving the use of synthetic oligonucleotides which flank the target sequences and which act as primers for the heat stable enzyme Taq polymerase. Repeated cycles of heat denaturation of the template DNA, annealing of the primers to their complementary sequences, and extension of the annealed primers by the $T a q$ polymerase result in the exponential production of the specific target fragment.

PCR has been used for the detection of CMV in urine, ${ }^{9-11}$ but problems have been encountered with inhibitory activity of urine. ${ }^{9}$ In preliminary studies we experienced similar problems when testing 45 randomly selected urine samples from infants, some of which were known to contain CMV by conventional virus isolation, and all gave negative results by PCR. This prompted us to investigate the nature of the inhibitory component of urine. We report the results of these studies and propose methods for the removal of the inhibitory component, as well as an improved amplification method for CMV DNA using nested oligonucleotide primers.

\section{Methods}

Urine samples from neonates and children of varying age up to 10 years old were selected from specimens submitted to the Virology Department for routine virus isolation and from a collection of specimens supplied by $\mathrm{Dr}$ J Booth (St George's Hospital Medical School) as part of a collaborative study. All urine samples were from original specimens stored at $-70^{\circ} \mathrm{C}$ without preservatives or transport medium added. Routine virus isolation had previously been performed on the urine specimens in human foreskin fibroblasts (HFF) or embryonic lung fibroblasts (HEL) maintained under Eagle's minimum essential medium supplemented with $5 \%$ fetal calf serum. Positive control material containing cytomegalovirus (CMV) DNA was prepared from HFF cultures infected with CMV (strain AD 169). Cultures showing about $80 \%$ cytopathic effect were scraped into phosphate buffered saline (PBS) ( $\mathrm{pH} \mathrm{7.3)} \mathrm{and} \mathrm{stored} \mathrm{in}$ aliquots at $-70^{\circ} \mathrm{C}$. 


\section{SAMPLE PREPARATION FOR PCR}

Urine samples were processed by dialysis or ultrafiltration before PCR. For dialysis, aliquots of 1-2 ml of urine were dialysed against 200 volumes of $0.1 \mathrm{M}$ TRIS- $\mathrm{HCl}$ buffer ( $\mathrm{pH} \mathrm{8.3)} \mathrm{overnight} \mathrm{at} 4^{\circ} \mathrm{C}$. The samples were stirred. Two commercial tube systems were used for ultrafiltration of urine specimens-Centricon-100 (Amicon) and Ultrafree MC Filter Units $100 \mathrm{~K}$ (Millipore). With the Centricon tubes, 1-2 $\mathrm{ml}$ of urine was placed in the filtration cup and filtered through almost to dryness by centrifugation in a Mistral 2L MSE centrifuge at $750 \mathrm{rpm}$ for $30-45$ minutes. The remainder was rinsed once with sterile distilled water and then recovered in sterile distilled water to the original volume by centrifugation at $500 \mathrm{rpm}$ for two to three minutes. With the Ultrafree MC cups, $200 \mu \mathrm{l}$ of urine were filtered by centrifugation at $6500 \mathrm{rpm}$ for five minutes in a microfuge (MSE). The retentate was rinsed once with $200 \mu$ l sterile distilled water and then carefully resuspended in a further $200 \mu \mathrm{l}$ sterile distilled water. In some experiments attempts were made to precipitate virus particles from urine with polyethylene glycol (PEG) by adding $0.1 \mathrm{ml} \mathrm{PEG}(50 \%$ stock in $0.1 \mathrm{M}$ phosphate buffer, $0.5 \mathrm{M} \mathrm{NaCl}$ ) to $0.4 \mathrm{ml}$ urine. After overnight incubation at $4^{\circ} \mathrm{C}$ the mixtures were centrifuged at $13000 \mathrm{rpm}$ for five minutes in a microfuge and pellets were resuspended in about $100 \mu \mathrm{l}$ sterile distilled water. Attempts were also made to solubilise virus particles from urine into the waterimmisible solvent ethyl acetate by shaking $0.5 \mathrm{ml}$ urine with an equal volume of ethyl acetate for two to five minutes. The mixtures were then left on the bench to separate and the solvent (top) layer was carefully recovered.

Aliquots of $100-200 \mu \mathrm{l}$ of untreated urine or material from processed urine samples were placed at $100^{\circ} \mathrm{C}$ for 15 minutes and $50 \mu \mathrm{l}$ of boiled samples were then used for PCR unless otherwise stated.

PREPARATION OF OLIGONUCLEOTIDE PRIMERS Oligonucleotides were custom synthesised using the $380 \mathrm{~B}$ or 391 DNA synthesisers (Applied Biosystems). The oligonucleotides were deprotected after synthesis, precipitated with ethanol, and used without further purification. CMV primer sets were chosen from the morphological transforming region II (mtrII). ${ }^{12}$ The sequences are given from $5^{\prime}$ to 3': CMTR 1-CTG TCG GTG ATG GTC TCT TC; CMTR 2-CCC GAC ACG CGG AAA AGA AA. These span a 234 base pair segment. A second set of "nested" primers were chosen from the same region: CMTR 3-TCT CTG GTC CTG ATC GTC TT; CMTR 4-GTG ACC TAC CAA CGT AGG TT, These span a 168 base pair segment located within the first primer pair.

DNA from uninfected human fibroblasts and cells infected with human herpes virus 6 (HHV-6), Epstein-Barr virus (EBV), herpes simplex virus (HSV) or varicella zoster virus (VZV) gave negative results by PCR with both the above primer sets.
POLYMERASE CHAIN REACTION

The PCR was performed essentially as described by Saiki et al, ${ }^{6}$ using cloned DNA polymerase from Thermus aquaticus (Amplitaq; Perkin-Elmer Cetus) and following the manufacturer's protocol. All preparative work for the PCR was carried out in an ultraviolet irradiated class II microbiological safety cabinet, using autoclaved plastic tubes and pipette tips throughout. Amplification reactions were carried out in a total volume of $100 \mu \mathrm{l}$ comprising $50 \mu \mathrm{l}$ reaction buffer and $50 \mu \mathrm{l}$ test sample in $0.6 \mathrm{ml}$ microcentrifuge tubes. The reaction buffer was prepared in bulk ("mastermix") at double strength-to give final concentrations of $10 \mathrm{mM}$ TRIS- $\mathrm{HCl}$ (pH 8.3) $50 \mathrm{mM} \mathrm{KCl}$, $1.5 \mathrm{mM} \mathrm{MgCl}_{2}, 0.01 \%$ gelatin, $0.2 \mathrm{mM}$ of each deoxynucleoside triphosphate and $0.2 \mu \mathrm{m}$ of each oligonucleotide primer-and stored in aliquots at $-20^{\circ} \mathrm{C}$. The required quantity of "mastermix" was thawed and the Amplitaq was added to give a final concentrations of 2.5 units per reaction tube. The reaction mixture was dispensed into $0.6 \mathrm{ml}$ microcentrifuge tubes and the test sample was added, either neat or appropriately diluted with sterile distilled water, using sterile $50 \mu \mathrm{l}$ glass capillaries. The reaction mixtures were overlayed with mineral oil (about $100 \mu \mathrm{l}$ ) to prevent evaporation. Reaction tubes containing positive and negative CMV DNA control samples were included in each batch of tests. The PCR was performed in a DNA Thermal Cycler (Perkin-Elmer Cetus) using the following amplification procedures:

Standard procedure The samples were amplified through 30 cycles consisting of denaturation at $94^{\circ} \mathrm{C}$ for one minute, annealing at $60^{\circ} \mathrm{C}$ for one minute and primer extension at $72^{\circ} \mathrm{C}$ for two minutes. During the final 10 cycles, the extension time was increased by 10 seconds with each cycle. After the final cycle the reaction tubes were left at $4^{\circ} \mathrm{C}$ until collected.

In some experiments a modified two stage procedure was used as previously described. ${ }^{13}$ Briefly, the test samples were initially amplified through 20 cycles in the presence of reduced deoxynucleoside triphosphates $(0.1 \mathrm{mM}$ of each), primers $(0.02 \mu \mathrm{M})$ and Amplitaq $(0.375$ units per tube). Aliquots of $5 \mu \mathrm{l}$ of these amplified products, plus $45 \mu \mathrm{l}$ of sterile distilled water were then transferred (in a separate room) to fresh reaction tubes, containing standard "mastermix", and 30 amplification cycles were performed according to the standard procedure.

Procedure with nested primers This was basically a modification of the above two stage procedure where the test samples and controls were initially subjected to 20 amplification cycles in the presence of reduced deoxynucleoside triphosphates, the first set of primers, and Amplitaq. Aliquots of $5 \mu \mathrm{l}$ of amplified samples were transferred to fresh reaction tubes containing "mastermix" with the nested primer set. The reactions were then performed according to the standard protocol for 30 cycles. 
Figure 1 Results of PCR for $C M V D N A$ on $(A)$ untreated and $(B)$ dialysed urines (lanes 1 10). Molecular weight markers $(M)$ and $C M V$ positive and negative control material were included the specific CMV Band at 234 base pairs is indicated.

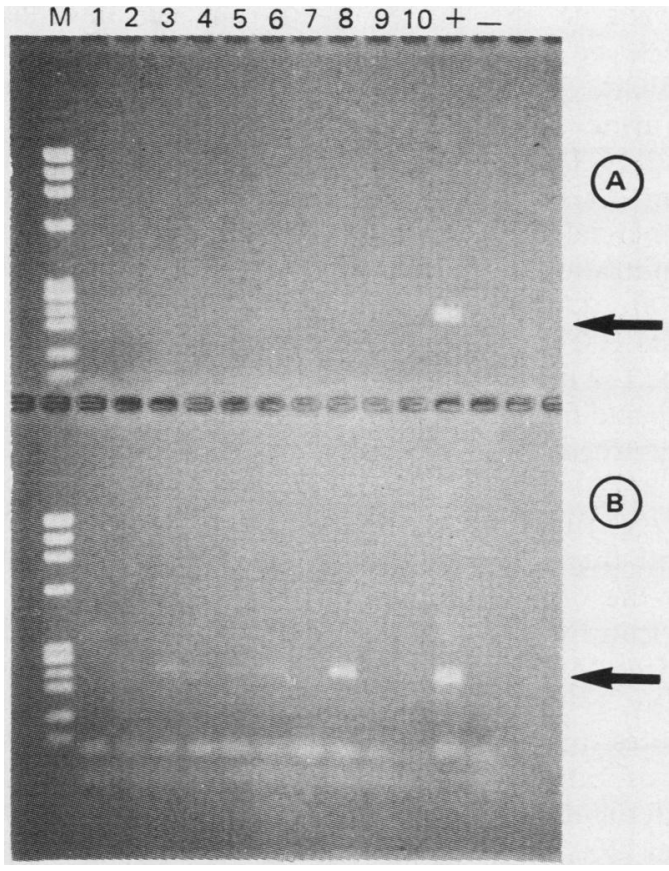

DETECTION OF AMPLIFICATION PRODUCTS

After PCR amplification the reaction soups were collected (in a separate laboratory) with sterile $100 \mu \mathrm{l}$ glass capillaries and $8 \mu \mathrm{l}$ aliquots were mixed with $2 \mu$ l of loading buffer $(0.25 \%$ bromophenol blue, $30 \%(\mathrm{w} / \mathrm{v})$ glycerol in water). Five or $10 \mu \mathrm{l}$ of each mixture were electrophoresed through $2 \%$ agarose gel (Sigma UK) at 100 volts. After electrophoresis the gels were stained with ethidium bromide and examined on an ultraviolet light transilluminator. The gels were photographed with a Polaroid camera and bands of the appropriate sizes were identified by comparison with DNA fragments of known size (Hae III digest of Phi X174 RF DNA; Gibco BRL).

The specificity of the amplified products after nested PCR was verified by Southern blotting and hybridisation with a biotinylated CMV probe (details to be published separately).

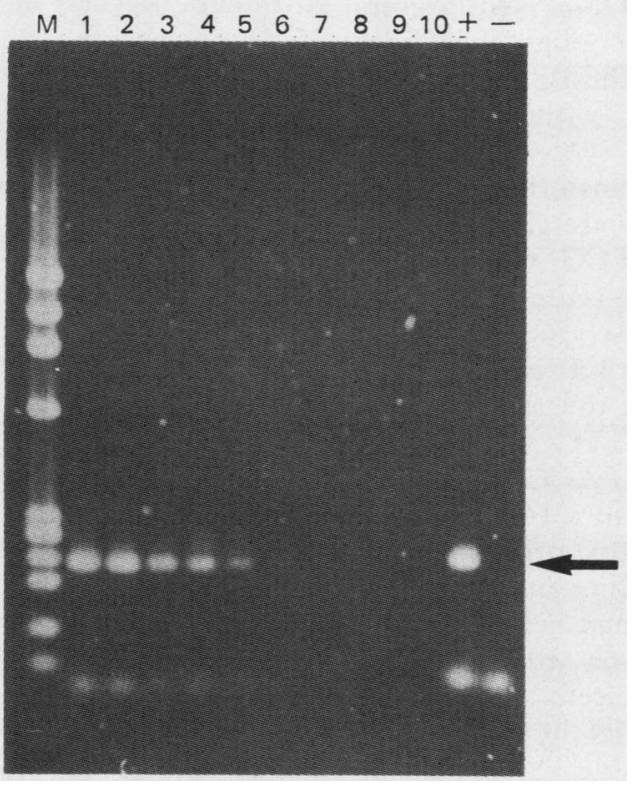

\section{Results}

In preliminary experiments 45 urine samples from neonates and young children were tested for CMV DNA by PCR, either neat or diluted 1 in 10 , or 1 in 50 in sterile distilled water, and all gave negative results, including samples which had been shown to contain CMV by virus isolation. Dialysis of the urine samples before the PCR rendered some of the samples positive (fig 1). It was concluded that a low molecular weight constituent of urine is inhibitory to the PCR.

\section{NATURE OF INHIBITORY ACTIVITY OF URINE ON PCR}

The inhibitory nature of urine on PCR was confirmed by mixing fresh adult urine at varying concentrations with CMV positive control material. Urine dilutions of up to 1 in 16 (equivalent to $3 \cdot 125 \mu \mathrm{l}$ in $100 \mu \mathrm{l}$ reaction mixture) completely inhibited the PCR. Sterile distilled water substituted for urine showed no such effect (results not shown).

Urea was thought to be an inhibitory substance in urine. A dilution series of urea in sterile distilled water was therefore mixed with CMV positive control material: it was shown that urea is completely inhibitory down to a final concentration of $100 \mathrm{mM}$ and partially inhibitory even at $50 \mathrm{mM}$ (fig 2). This effect could be overcome by dialysis before the PCR.

The inhibitory activity of urine in relation to the concentrations of urea, creatinine, and electrolytes was investigated next using five neonatal urine samples and five urine samples from children under 10 years old (table 1 ). The urine samples were mixed at ratios of $9: 1(90 \%)$ and $1: 9(10 \%)$ with positive CMV control material, and $50 \mu \mathrm{l}$ of the mixtures were then used for the PCR. The inhibitory activity of the urine samples showed a correlation with the urea concentration but not with creatinine or electrolytes (table 1). Thus urea concentrations between 68 and $165 \mathrm{mM}$ were inhibitory with the $90 \%$ mixtures but not at $10 \%$, while one urine with $325 \mathrm{mM}$ urea was inhibitory with both mixtures (fig 3). Urea concentrations of $\leqslant 43 \mathrm{mM}$ (mainly in neonatal urine samples) were not inhibitory except with one urine (No 19) which had an exceptionally low urea concentration of $10 \mathrm{mM}$.

Further chemical analyses of these 10 urines showed no abnormalities (table 2 ) that could be correlated with their inhibitory activity in the PCR, except that the inhibitory neonatal urine (No 19) with low urea was reactive for glucose. To determine whether this was a common finding a further eight neonatal urine samples, with urea concentrations ranging from 9.9 to $170 \mathrm{mM}$ (mean $49.6 \mathrm{mM}$ ) were tested for inhibitory activity in $90 \%$ mixtures with CMV control material. Once again, the urine sample with the lowest urea concentration was unexpectedly found to be inhibitory and was reactive for glucose.

Glucose mixed with the CMV control, however, was not in itself inhibitory in the PCR at concentrations ranging from $15-500 \mathrm{mM}$. One possible source of glucose in neonatal urine is from parenteral feeding, and while it 
Table 1 Inhibitory effects of urines on PCR in relation to concentrations of urea, creatinine, and electrolytes

\begin{tabular}{|c|c|c|c|c|c|c|c|}
\hline \multirow[b]{3}{*}{ Urine sample } & \multirow[b]{3}{*}{ Urea (mmol/l) } & \multirow[b]{3}{*}{ Creatinine (mmol/l) } & \multirow[b]{3}{*}{$\mathrm{Na}+(\mathrm{mmol} /)$} & \multirow[b]{3}{*}{$K+(\mathrm{mmol} / \mathrm{l})$} & \multicolumn{3}{|c|}{ Inhibition of PCR } \\
\hline & & & & & \multicolumn{2}{|c|}{ Undialysed } & \multirow{2}{*}{$\begin{array}{l}\text { Dialysed } \\
90 \%\end{array}$} \\
\hline & & & & & $10 \%$ & $90 \%$ & \\
\hline $\begin{array}{l}\text { Neonates: } \\
16 \\
19 \\
22 \\
23 \\
37\end{array}$ & $\begin{array}{r}165 \\
10 \\
43 \\
18 \\
40\end{array}$ & $\begin{array}{r}11.5 \\
1.0 \\
3.0 \\
0.8 \\
0.8\end{array}$ & $\begin{array}{r}70 \\
132 \\
62 \\
3.0 \\
7.0\end{array}$ & $\begin{array}{c}76 \\
29 \\
20 \\
9 \cdot 0 \\
24\end{array}$ & $\begin{array}{l}\overline{-} \\
\overline{-} \\
\overline{-}\end{array}$ & $\begin{array}{l}+ \\
+ \\
- \\
-\end{array}$ & $\begin{array}{l}\overline{N D} \\
- \\
- \\
-\end{array}$ \\
\hline $\begin{array}{l}\text { Children: } \\
9 \\
14 \\
15 \\
28 \\
43\end{array}$ & $\begin{array}{r}325 \\
85 \\
134 \\
68 \\
129\end{array}$ & $\begin{array}{r}19 \cdot 0 \\
8 \cdot 2 \\
4 \cdot 1 \\
8.9 \\
9 \cdot 7\end{array}$ & $\begin{array}{r}\text { ND } \\
>200 \\
70 \\
>200 \\
138\end{array}$ & $\begin{array}{r}\text { ND } \\
69 \\
13 \\
120 \\
31\end{array}$ & $\begin{array}{l}+ \\
- \\
- \\
-\end{array}$ & $\begin{array}{l}+ \\
+ \\
+ \\
+ \\
+\end{array}$ & $\begin{array}{l}\text { ND } \\
- \\
- \\
- \\
-\end{array}$ \\
\hline
\end{tabular}

$\mathrm{ND}=$ Not done due to insufficient sample.

was not possible to ascertain with the two aforementioned neonates whether they had received such feeding, standard parenteral nutrition formulation (Kendall Laboratories Ltd) completely inhibits the PCR down to $70 \%$ concentration mixed with positive CMV control material (results not shown).

\section{REMOVAL OF INHIBITORY ACTIVITY OF URINE}

Dialysis was considered too cumbersome as a routine method for treating urine samples before the PCR and alternative methods were therefore evaluated. Preliminary attempts to destroy urea by adding urease or by boiling with acid or alkali proved unsuccessful. Similarly, separation of virus particles from urine by PEG precipitation or shaking with ethyl acetate also failed. Ultrafiltration seems to provide the best alternative at present to dialysis for the removal of the inhibitory activity of urine. Two filtration systems were compared-the Centricon-100 tubes and the Millipore cups. Both use centrifugation and effectively remove inhibitory activity. The Millipore cups take smaller volumes however, and are cheaper and faster to use.

Figure 3 Inhibitory effect of urines from neonates (lanes 1-5) and children (lanes 6-10) mixed at a concentration of $(A) 10 \%$ or $(B) 90 \%$ with $C M V$ positive control material (lane 12). Molecular weight markers $(M)$ are included and the specific $C M V$ band at 234 base pairs is indicated.

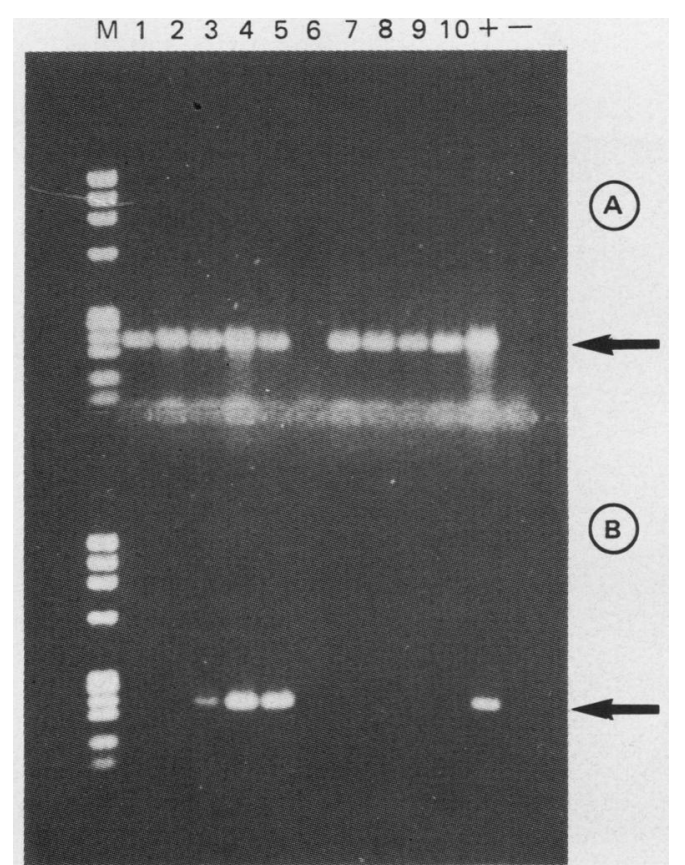

"NESTED" PRIMER PCR

Although the inhibitory activity of urine could be effectively removed by ultrafiltration, the bands obtained under ultraviolet light after the PCR, according to the standard protocol, were very weak with some urine samples, and it was felt that this method bordered the limits of sensitivity required for routine use. To increase sensitivity a two-stage PCR method was attempted first, which consisted of preamplification for 20 cycles followed by the standard protocol. Although this method increased the band intensity, it also gave extensive background staining (fig 4A). Primer dimer formation was particularly noticeable with this method.

The two-stage method was modified by using "nested" primers in the second ( 30 cycle) reaction which were chosen from within the fragment amplified by the first set of primers. Preliminary evaluation of nested PCR, using serial dilutions of $\mathrm{CMV}$ positive control material, showed that it was at least 10 times more sensitive than conventional PCR (not shown), and with the urine samples it gave much stronger bands with virtually no background staining or primer dimers (fig 4B). This therefore seems to be the optimal method, in combination with ultrafiltration, for detecting CMV DNA in urine samples. A large scale evaluation of this method as a diagnostic test is currently under way.

\section{Discussion}

The development of the PCR has revolutionised the detection and analysis of nucleic acids. Within the past two years it has established itself as one of the most promising tools of molecular biology to be applied both for research purposes and routine diagnosis. ${ }^{14-16}$ The PCR is technically relatively simple to perform yet offers a very high level of sensitivity. Further attractions are that as a technique it can be used to detect virtually all infectious agents and on a wide variety of specimens. It has therefore been used for the detection of viral DNA or RNA in peripheral blood, ${ }^{1719}$ in urine, ${ }^{91020}$ and even paraffin wax embedded, formalin fixed tissue ${ }^{21-23}$ using simple extraction procedures. ${ }^{13}$ 
Table 2 Chemical analyses ${ }^{\star}$ on urines showing inhibitory activity in PCR

\begin{tabular}{|c|c|c|c|c|c|c|c|}
\hline Urine sample & $p H$ & Protein & Glucose & Ketones & Urobilinogen & Bilirubin & Blood \\
\hline $\begin{array}{l}\text { Neonates: } \\
16 \\
19 \\
22 \\
23 \\
37\end{array}$ & $\begin{array}{l}5 \cdot 0 \\
5 \cdot 5 \\
6 \cdot 0 \\
6 \cdot 0 \\
6 \cdot 0\end{array}$ & $\begin{array}{l}- \\
- \\
- \\
- \\
-\end{array}$ & $\begin{array}{l}- \\
5 \mathrm{mmol} / \mathrm{l} \\
- \\
- \\
-\end{array}$ & $\begin{array}{l}- \\
- \\
- \\
- \\
-\end{array}$ & $\begin{array}{l}- \\
- \\
- \\
-\end{array}$ & $\begin{array}{l}- \\
- \\
- \\
- \\
-\end{array}$ & $\begin{array}{l}- \\
- \\
- \\
-\end{array}$ \\
\hline $\begin{array}{l}\text { Children: } \\
9 \\
14 \\
15 \\
28 \\
43\end{array}$ & $\begin{array}{l}5 \cdot 5 \\
5 \cdot 5 \\
6 \cdot 0 \\
6 \cdot 5 \\
6 \cdot 5\end{array}$ & $\begin{array}{l}- \\
- \\
- \\
-\end{array}$ & $\begin{array}{l}- \\
- \\
- \\
- \\
-\end{array}$ & $\begin{array}{l}- \\
- \\
- \\
- \\
-\end{array}$ & $\begin{array}{l}- \\
- \\
- \\
- \\
-\end{array}$ & $\begin{array}{l}- \\
- \\
- \\
-\end{array}$ & $\begin{array}{l}- \\
- \\
- \\
-\end{array}$ \\
\hline
\end{tabular}

The PCR is essentially an enzyme reaction and requires carefully controlled conditions for efficient amplification. It is therefore not surprising to find that it may be susceptible to interference by metabolites, drugs (especially nucleoside analogues), or other biological substances found in the body fluids of patients. This is an area which will undoubtedly require careful investigation in the future.

Urine could be expected to present particular problems in the PCR as it is the main vehicle for excretion of breakdown products and drugs from the body, and its composition is therefore highly variable. It is also the commonest site of virus excretion in those infected with $\mathrm{CMV}$ and this plays an important part in the diagnosis of congenital $\mathrm{CMV}$ infections. Other investigators using PCR for the detection of CMV in urine have reported problems with inhibitory activity. ${ }^{9}$ We have shown that urea is a potent inhibitor of the PCR, completely inhibiting the reaction at concentrations of more than $50 \mathrm{mM}$. The normal concentration of urea in adult urine is about $330 \mathrm{mM}$.

Furthermore, we showed that the inhibitory activity of urine samples from neonates and older children was directly related to the urea concentrations in these urine samples. Neonatal urine samples generally contain less urea than those from older children and were found

Figure 4 Comparison of results with $(A)$ two stage $P C R$ and $(B)$ nested primer PCR. Lanes 1-8 show results with urines after ultrafiltration, Lanes 9-13 show results with dialysed urines. Specific $C M V$ bands at 234 and 168 , base pairs,

respectively, are indicated.

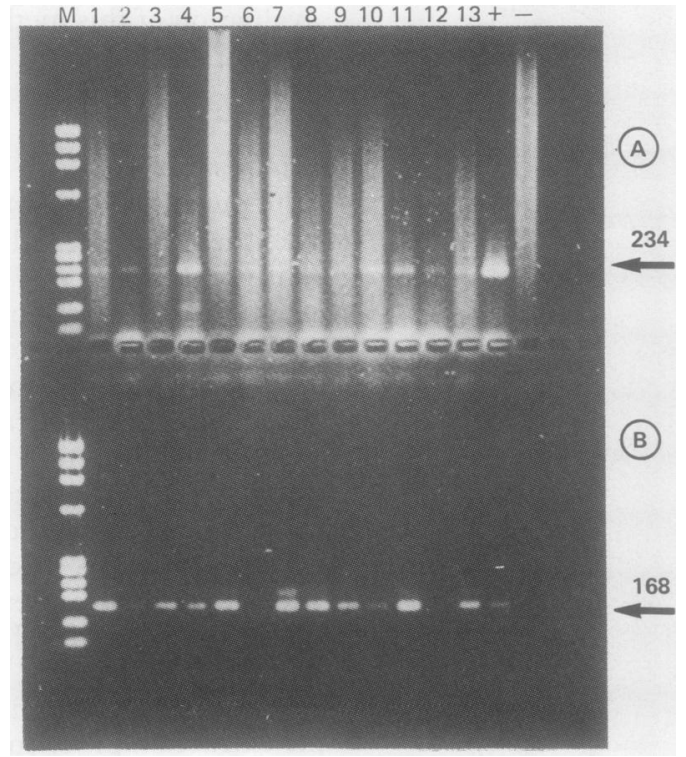

to be less inhibitory in the PCR. Urea therefore seems to be the predominant inhibitory constituent of urine. The nature of this inhibitory activity is not known, but urea is a potent inhibitor of non-covalent bonding and may act directly on the polymerase, or it may prevent primer annealing. Two neonatal urine samples were found to be inhibitory in spite of low urea concentrations. Both contained glucose and while we did not identify the cause of this activity it is likely that it originated from parenteral nutrition, which we found to be inhibitory in its supplied, packaged form. The diversity of potentially inhibitory substances that may be excreted in patients' urine has to be taken into account when attempting their removal before using PCR. Prior dilution of the urine $^{9}$ to reduce the urea concentration may be effective with most neonatal urine samples but will require a dilution factor of at least 1 in 10 to 1 in 20 to prevent the risk of any inhibition. This does not allow for the possibility, however, that other, more potent inhibitors may be present occasionally. Furthermore, it inevitably reduces the sensitivity of the technique which may be important because infected neonates may excrete as little CMV as $10^{3}$ particles $/ \mathrm{ml} .{ }^{5}$ We have shown that ultrafiltration is a simple and effective method for the removal of low molecular weight inhibitors from urine samples. Small samples of urine can be processed easily within 10-15 minutes before using the PCR and at minimal cost using the Millipore centrifuge cups. If required, the urine samples can be concentrated during this process. Despite the successful removal of inhibitory activity of urine the virus specific bands were still often found to be weak under ultraviolet light. Attempts to increase the sensitivity by increasing the number of cycles invariably led to increased background. The use of nested primers and a modified two-stage PCR protocol, using reduced reactants, significantly increased both sensitivity and specificity of the reaction.

We are grateful to Dr Ian Lamb for the synthesis of the oligonucleotide primers and to Dr P Sanders for the urinalysis. This study was supported by a grant from the Joint Research Board of St Bartholomew's Hospital. 
1 Glenn J. Cytomegalovirus infection following renal transplantation. Rev Infect Dis 1981;3:1151-78.

2 Drew WL. Cytomegalovirus infection in patients with AIDS. J Infect Dis 1988;158:449-56.

3 Stagno S, Pass RF, Dworsky ME, et al. Congenital cytomegalovirus infection: the relative importance of primary and recurrent maternal infections. $N$ Engl J Med 1982;306:945-9.

4 Stirk PR, Griffiths PD. Use of monoclonal antibodies for the diagnosis of cytomegalovirus infection by the detection of early antigen fluorescent foci (DEAFF) in cell culture. $J$ Med Virol 1987;21:329-37.

5 Stagno S, Pass RF, Reynolds DW, Moore MA, Nahmias AJ, Alford CA. Comparative study of diagnostic procedures for congenital cytomegalovirus infection. Pediatrics 1980;65:251-7.

6 Saiki RK, Gelfand DH, Stoffel S, et al. Primer-directed enzymatic amplification of DNA with a thermostable DNA polymerase. Science 1988;239:487-91.

7 Saiki RK, Scharf SJ, Falaona F, et al. Enzymatic amplification of B-globin genomic sequences and restriction site analysis for diagnosis of sickle-cell anaemia. Science 1985;230:1350-4

8 Schochetman G, Ou CY, Jones WK. Polymerase chain reaction. J Infect Dis 1988;158:1154-7.

9 Demmler GJ, Buffone GJ, Schimbor CM, May RA. Detection of cytomegalovirus in urine from newborns by using polymerase chain reaction DNA amplification. $J$ Infect Dis 1988;158:1177-84.

10 Olive DM, Al Mufti S, Simsek M, Fayez H, Al Nakib W. Direct detection of human cytomegalovirus in urine specimens from renal transplant patients following specimens from renal transplant patients following polymerase chain

11 Olive DM, Simsek M, Al Mufti S. Polymerase chain reaction assay for detection of human cytomegalovirus. $J$ Clin Microbiol 1989;27:1238-42.

12 Razzaque A, Jahan N, McWeeeney D, et al. Localisation of DNA sequence analysis of the transforming domain (mtr
II) of human cytomegalovirus. Proc Natl Acad Sci USA 1988;85:5709-13.

13 Coates PJ, d'Ardenne AJ, Khan G, Kangro HO, Slavin G. Simplified procedures for applying the polymerase chain reaction to routinely fixed paraffin wax sections. J Clin Pathol 1990;43:115-8.

14 Bell J. The polymerase chain reaction. Immunology Today 1989;10:351-5.

15 Erlich HA. Ed. PCR Principles and applications for DNA amplification. New York: Stockton Press, 1990.

16 Marx JL. Multiplying genes by leaps and bounds. Science 1988;240:1408-10.

17 Jiwa NM, Van Gemert GW, Raap AK, et al. Rapid detection of human cytomegalovirus DNA in peripheral blood leucocytes of viremic transplant recipients by the polymerase chain reaction. Transplantation 1989;48:72-6.

18 Rogers MF, Ou CY, Rayfield M, et al. Use of polymerase chain reaction for early detection of the proviral sequences of human immunodeficiency virus in infants born to seropositive mothers. N Engl J Med 1989;320:1649-53.

19 Gopal MR, Thompson BJ, Fox J, Tedder RS, Honess RW. Detection by PCR of HHV -6 and EBV DNA in blood and oropharynx of healthy adults and HIV seropositives. Lancet 1990;335:1598-9.

$20 \mathrm{Li}$ JJ, Friedman-Kien AE, Huang Y, Mirabile M, Cao Y HIV-1 DNA proviral sequences in fresh urine pellets from HIV-1 seropositive persons. Lancet 1990;335:1590-1.

21 Griffin NR, Bevan IS, Lewis FA, Wells M, Young LS Demonstration of multiple HPV types in normal cervix and in cervical squamous cell carcinoma using the polymerase chain reaction on paraffin wax embedded material. J Clin Pathol 1990;43:52-6.

22 Shibata DK, Amheim N, Martin J. Detection of human papilloma virus in paraffin-embedded tissue using the papilloma virus in paraffin-embedded tissue using the

23 Lo YMD, Mehal WZ, Fleming A. In vitro amplification of hepatitis B virus sequences from liver tumour DNA and from paraffin wax embedded tissue using the polymerase chain reaction. J Clin Pathol 1989;42:840-6. 